\title{
Keterlaksanaan Penilaian Kompetensi Keterampilan Pada Pembelajaran Matematika Berdasarkan Kurikulum 2013
}

\author{
Sintha Sih Dewanti \\ Fakultas Sains dan Teknologi, UIN Sunan Kalijaga Yogyakarta \\ email: sintha_pmat@yahoo.com
}

\begin{abstract}
Abstrak
Penelitian ini bertujuan untuk mendeskripsikan: 1) pemahaman guru terhadap penilaian kompetensi keterampilan; 2) penerapan penilaian kompetensi keterampilan pada pembelajaran matematika; dan 3) problematika guru dalam menerapkan penilaian kompetensi keterampilan. Penelitian ini menggunakan pendekatan kualitatif dengan jenis penelitian deskriptif. Penelitian dilakukan pada tahun ajaran 2017/2018 dan dilaksanakan di 9 SMP/ MTs di wilayah DIY. Subjek penelitian sebanyak 11 orang guru matematika yang dipilih dengan menggunakan teknik purpossive sampling. Teknik pengumpulan data yang digunakan adalah metode wawancara terstruktur, observasi dan dokumentasi. Data dianalisis dengan menggunakan logika induktif, yakni dari khusus ke umum. Hasil penelitian menunjukkan bahwa: 1) pemahaman guru terhadap penilaian kompetensi keterampilan ini cukup baik, guru paham mengenai macam instrumen dan teknik penilaian, akan tetapi belum memahami rubrik penilaian yang digunakan pada setiap instrumen; 2) penerapan penilaian kompetensi keterampilan sudah berjalan dengan cukup baik namun beberapa masih terkendala dan belum sesuai standar penilaian; 3) problematika guru dalam menerapkan penilaian kompetensi keterampilan yaitu: masalah pemahaman penilaian kompetensi keterampilan, waktu, kompleksitas administrasi, keadaan siswa, perencanaan penilaian diantaranya pengembangan instrumen dan rubrik penilaian, dan pelaksanaan penilaian kompetensi keterampilan.
\end{abstract}

Kata kunci: keterlaksanaan penilaian, penilaian kompetensi keterampilan, Kurikulum 2013

\begin{abstract}
This study aims to describe: 1) teachers' understandings of skill competency assessment; 2) the application of skills competency assessment in mathematics learning; and 3) teachers' problematics in applying skills competency assessments. This research used qualitative approach with descriptive research type. The study was conducted in the academic year 2017/2018 and implemented in 9 junior high schools / Islamic junior high schools in DIY region. Research subjects were 11 mathematics teachers who are selected using purposive sampling technique. The data collected through structured interviewing methods, observation, and documentation. The data were analyzed by using inductive logic, from the particular to the general. The results show that: 1) teachers' understandings of skills competency assessment are quite good. Teachers understood the various instruments and assessment techniques but have not understand the assessment rubric used in each instrument yet; 2) the application of skills competency assessment has already done well but some were still constrained and have not accorded to the assessment standards; 3) teachers' problematics in applying skill competency assessment are: problems of understanding skill competency assessment, time, administrative complexity, student condition, assessment planning including the development of instrument and assessment rubric, and the implementation of skill competency assessment.
\end{abstract}

Keywords: assessment execution, skill competency assessment, Curriculum 2013 
Keterlaksanaan Penilaian Kompetensi Keterampilan Pada Pembelajaran Matematika Berdasarkan Kurikulum 2013

Sintha Sih Dewanti

\section{PENDAhUluan}

Perubahan yang mendasar pada proses pembelajaran dengan Kurikulum 2013 juga berdampak pada sistem penilaian yang lebih mengarah ke penilaian autentik. Menurut Dewanti (2015), penilaian autentik memiliki relevansi yang kuat terhadap pendekatan saintifik dalam pembelajaran sesuai dengan tuntutan Kurikulum 2013. Penilaian semacam ini mampu menggambarkan peningkatan hasil belajar siswa, baik dalam rangka mengobservasi, menalar, mencoba, membangun jejaring, dan lain-lain. Penilaian autentik cenderung fokus pada tugas-tugas kompleks atau kontekstual yang memungkinkan siswa untuk menunjukkan kompetensi mereka yang lebih autentik.

Implementasi Kurikulum 2013 berimplikasi pada model penilaian pencapaian kompetensi siswa. Penilaian pencapaian kompetensi merupakan proses sistematis dalam mengumpulkan, menganalisis dan menginterpretasi informasi untuk menentukan sejauhmana siswa telah mencapai tujuan pembelajaran. Sesuai dengan Permendikbud RI No. 23 Tahun 2016 tentang Standar Penilaian Pendidikan, penilaian pencapaian kompetensi pada jenjang pendidikan dasar dan menengah dilaksanakan oleh pendidik, satuan pendidikan, pemerintah dan/ atau lembaga mandiri. Penilaian pencapaian kompetensi oleh guru dilakukan untuk memantau proses, kemajuan, perkembangan pencapaian kompetensi siswa sesuai dengan potensi yang dimiliki dan kemampuan yang diharapkan secara berkesinambungan. Penilaian juga dapat memberikan umpan balik kepada guru agar dapat menyempurnakan perencanaan dan proses pembelajaran.

Penilaian oleh guru merupakan suatu proses yang dilakukan melalui langkah-langkah perencanaan, penyusunan alat penilaian, pengumpulan informasi melalui sejumlah bukti yang menunjukkan pencapaian kompetensi siswa, pengolahan, dan pemanfaatan informasi tentang pencapaian kompetensi siswa. Penilaian pencapaian kompetensi baik formal maupun informal diadakan dalam suasana yang menyenangkan, sehingga memungkinkan siswa menunjukkan apa yang dipahami dan mampu dikerjakannya. Pencapaian kompetensi seorang siswa dalam periode waktu tertentu dibandingkan dengan hasil yang dimiliki siswa tersebut sebelumnya dan tidak dianjurkan untuk dibandingkan dengan siswa lainnya. Dengan demikian siswa tidak merasa dihakimi oleh guru tetapi dibantu untuk mencapai kompetensi atau indikator yang diharapkan.

Ruang lingkup penilaian menurut Permendikbud RI No. 23 Tahun 2016 mencakup kompetensi sikap, pengetahuan, dan keterampilan yang dilakukan secara berimbang menggunakan teknik penilaian tertentu. Maka dari itu, penilaian hasil belajar oleh guru dilakukan secara berkesinambungan dan mencakup seluruh kompetensi pada diri siswa sesuai dengan karakteristik mata pelajaran.

Penilaian merupakan kegiatan sangat penting dalam pembelajaran matematika. Penilaian dapat memberikan umpan balik yang konstruktif bagi guru maupun siswa. Berdasarkan hasil penilaian, guru dapat mengambil keputusan secara tepat untuk menentukan langkah yang harus dilakukan selanjutnya. Guru juga dapat mengetahui seberapa jauh keberhasilan belajar matematika siswa, serta ketepatan metode mengajar yang digunakan. Hasil penilaian juga dapat memberikan motivasi kepada siswa untuk berprestasi lebih baik. Bahkan penilaian dapat mempengaruhi perilaku belajar karena siswa cenderung mengarahkan kegiatan belajarnya menuju muara penilaian yang dilakukan guru. Oleh karena pentingnya penilaian, setiap guru matematika harus memiliki pemahaman yang benar tentang berbagai aspek penilaian, baik pengertian, objek, teknik maupun jenis penilaian, sehingga dapat merancang dan 
Halaman 59-68

melaksanakan penilaian pembelajaran matematika dengan baik.

Objek penilaian merujuk pada apa yang menjadi sasaran dari penilaian pembelajaran matematika. Sampai saat ini, banyak yang lebih menekankan pembelajaran matematika pada penguasaan materi matematika dan aplikasinya untuk memecahkan masalah yang berhubungan dengan materi matematika. Situasi ini menyebabkan penilaian pembelajaran matematika hanya berorientasi pada pengukuran domain yang dangkal dan sempit, tidak menyasar kompetensi matematis yang lebih tinggi. Praktek ini berdampak tidak optimalnya hasil belajar matematika.

Permendiknas RI No 16 tahun 2007 tentang Standar Kualifikasi Akademik dan Kompetensi Guru mengamanatkan bahwa penilaian harus sesuai dengan karakteristik mata pelajaran. Karakteristik matematika mengarahkan visi matematika pada dua arah pengembangan, yaitu untuk memenuhi kebutuhan masa kini dan kebutuhan masa datang (Sumarmo, 2010). Visi pertama mengarahkan pembelajaran matematika untuk pemahaman konsep dan ide matematika yang diperlukan untuk menyelesaikan masalah matematika dan ilmu pengetahuan lainnya (mathematical problem solving). Visi kedua dalam arti yang lebih luas dan mengarah ke masa depan, matematika memberi peluang berkembangnya kemampuan berpikir logis, sistematik, kritis dan cermat, kreatif, menumbuhkan rasa percaya diri, dan rasa keindahan terhadap keteraturan sifat matematika, serta mengembangkan sikap obyektif dan terbuka. Kedua visi tersebut harus menjadi perhatian juga dalam penilaian.

Dari uraian di atas disimpulkan bahwa objek penilaian pembelajaran matematika tidak hanya penguasaan materi oleh siswa, tetapi juga penguasan kompetensi sesuai tujuan pembelajaran matematika di sekolah. Namun, pada kenyataannya penilaian yang berjalan selama ini belum sesuai dengan standar penilaian pendidikan (Permendikbud RI No. 23 Tahun 2016). Penilaian selama ini lebih difokuskan pada penilaian kompetensi kognitif dengan teknik tes. Untuk itu perlu dilakukan penelitian mengenai keterlaksanaan penilaian kompetensi keterampilan pada pembelajaran matematika berdasarkan kurikulum 2013.

\section{KAJIAN TEORI}

\section{a. Pengertian Penilaian Pencapaian Kompetensi Keterampilan}

Penilaian pencapaian kompetensi keterampilan merupakan penilaian yang dilakukan terhadap siswa untuk menilai sejauh mana pencapaian SKL, KI, dan KD khusus dalam dimensi keterampilan. Pada Permendikbud RI No. 20 Tahun 2016 tentang Standar Kompetensi Lulusan Pendidikan Dasar dan Menengah disebutkan bahwa SKL dimensi keterampilan untuk satuan pendidikan tingkat $\mathrm{SMP} / \mathrm{MTs} /$ SMPLB/ Paket B adalah lulusan memiliki keterampilan berpikir dan bertindak: kreatif, produktif, kritis, mandiri, kolaboratif, dan komunikatif melalui pendekatan ilmiah sesuai dengan yang dipelajari di satuan pendidikan dan sumber lain secara mandiri. SKL ini merupakan tagihan kompetensi minimal setelah siswa menempuh pendidikan selama 3 tahun atau lebih dan dinyatakan lulus.

\section{b. Cakupan Penilaian Pencapaian Kompetensi Keterampilan \\ Cakupan penilaian dimensi}

keterampilan meliputi keterampilan siswa yang dipelajari di sekolah dan sumber lain yang sama dalam sudut pandang/ teori. Keterampilan ini meliputi: keterampilan mencoba, mengolah, menyaji, dan menalar. Dalam ranah konkret keterampilan ini mencakup aktivitas menggunakan, mengurai, merangkai, memodifikasi, dan membuat. Dalam ranah abstrak, keterampilan ini mencakup aktivitas menulis, membaca, menghitung, menggambar, dan mengarang. 


\section{c. Sasaran Penilaian Pencapaian Kompetensi Keterampilan \\ Berdasarkan Permendikbud RI}

Nomor 104 Tahun 2014 ada 2 sasaran penilaian hasil belajar pada kompetensi keterampilan yaitu: keterampilan abstrak dan keterampilan konkrit. Keterampilan abstrak berupa kemampuan belajar dalam kegiatan sebagai berikut.

1) Mengamati: perhatian pada waktu mengamati suatu objek/membaca suatu tulisan/ mendengar suatu penjelasan, catatan yang dibuat tentang yang diamati, kesabaran, waktu (on task) yang digunakan untuk mengamati.

2) Menanya: jenis, kualitas, dan jumlah pertanyaan yang diajukan siswa (pertanyaan faktual, konseptual, prosedural, dan hipotetik).

3) Mengumpulkan informasi/ mencoba: jumlah dan kualitas sumber yang dikaji/ digunakan, kelengkapan informasi, validitas informasi yang dikumpulkan, dan instrumen/ alat yang digunakan untuk mengumpulkan data.

4) Menalar/ mengembangkan mengasosiasi: interpretasi, argumentasi dan kesimpulan mengenai keterkaitan informasi dari dua fakta/ konsep, interpretasi argumentasi dan kesimpulan mengenai keterkaitan lebih dari dua fakta/ konsep/ teori, mensintesis dan argumentasi serta kesimpulan keterkaitan antar berbagai jenis fakta/ konsep/ teori/ pendapat; mengembangkan interpretasi, struktur baru, argumentasi, dan kesimpulan yang menunjukkan hubungan fakta/ konsep/ teori dari dua sumber atau lebih yang tidak bertentangan; mengembangkan interpretasi, struktur baru, argumentasi dan kesimpulan dari konsep/ teori/ pendapat yang berbeda dari berbagai jenis sumber.

5) Mengomunikasikan: menyajikan hasil kajian (dari mengamati sampai menalar) dalam bentuk tulisan, grafis, media elektronik, multi media dan lain-lain.

Sasaran penilaian hasil belajar pada keterampilan konkret sebagai berikut.

1) Persepsi (perception): menunjukan perhatian untuk melakukan suatu gerakan.

2) Kesiapan (set): menunjukan kesiapan mental dan fisik untuk melakukan suatu gerakan.

3) Meniru (guided response): meniru gerakan secara terbimbing.

4) Membiasakan gerakan (mechanism): melakukan gerakan mekanistik.

5) Mahir (complex or overt response): melakukan gerakan kompleks dan termodifikasi.

6) Menjadi gerakan alami (adaptation): menjadi gerakan alami yang diciptakan sendiri atas dasar gerakan yang sudah dikuasai sebelumnya.

7) Menjadi tindakan orisinal (origination): menjadi gerakan baru yang orisinal dan sukar ditiru oleh orang lain dan menjadi ciri khasnya.

\section{d. Teknik penilaian kompetensi keterampilan \\ Berdasarkan Permendikbud RI} Nomor 104 Tahun 2014, penilaian kompetensi keterampilan dapat dilakukan dengan menggunakan unjuk kerja/ kinerja/ praktik, proyek, pembuatan produk, portofolio, dan tertulis. Berikut ini akan diuraikan dari masing-masing teknik penilaian kompetensi keterampilan.

1) Penilaian unjuk kerja adalah penilaian yang menuntut respon berupa keterampilan melakukan suatu aktivitas atau perilaku sesuai dengan tuntutan kompetensi. Penilaian praktik dilakukan dengan mengamati kegiatan siswa dalam melakukan sesuatu. Penilaian digunakan untuk menilai ketercapaian kompetensi yang menuntut siswa melakukan tugas tertentu.

2) Penilaian proyek adalah tugas-tugas belajar (learning tasks) yang meliputi 
kegiatan perancangan, pelaksanaan, dan pelaporan secara tertulis maupun lisan dalam waktu tertentu. Penilaian proyek merupakan kegiatan penilaian terhadap suatu tugas yang harus diselesaikan dalam periode atau waktu tertentu. Tugas tersebut berupa suatu investigasi sejak dari perencanaan, pengumpulan, pengorganisasian, pengolahan dan penyajian data. Penilaian proyek dapat digunakan untuk mengetahui pemahaman, kemampuan mengaplikasikan, penyelidikan dan menginformasikan siswa pada matematika dan indikator/ topik tertentu secara jelas.

3) Penilaian produk meliputi penilaian kemampuan siswa membuat produk misalnya poster berupa peta konsep dalam materi matematika, grafik suatu fungsi, dan media pembelajaran matematika berupa alat peraga matematika dan software.

4) Penilaian portofolio adalah penilaian yang dilakukan dengan cara menilai kumpulan seluruh karya siswa dalam bidang tertentu yang bersifat reflektifintegratif untuk mengetahui minat, perkembangan, prestasi, dan/ atau kreativitas siswa dalam kurun waktu tertentu. Karya tersebut dapat berbentuk tindakan nyata yang mencerminkan kepedulian siswa terhadap lingkungannya.

5) Penilaian tertulis dapat digunakan untuk menilai kompetensi keterampilan seperti membuktikan suatu teorema dan menulis laporan proyek dan pembuatan produk.

\section{METODE PENELITIAN}

Penelitian ini menggunakan pendekatan kualitatif dengan jenis penelitian deskriptif. Penelitian dilakukan pada tahun ajaran 2017/2018 dan dilaksanakan di 9 SMP/ MTs di wilayah DIY baik negeri maupun swasta, yaitu: SMP Negeri 9 Yogyakarta, SMP Negeri 15 Yogyakarta, SMP Negeri 1
Imogiri, SMP Negeri 1 Sedayu, SMP Muhammadiyah 9 Yogyakarta, SMP Muhammadyah 3 Depok Sleman, MTs Negeri 1 Yogyakarta, MTs Negeri 4 Bantul, dan MTs Negeri 9 Bantul. Subjek penelitian sebanyak 11 orang guru matematika yang dipilih dengan menggunakan teknik purpossive sampling. Teknik pengumpulan data yang digunakan adalah metode wawancara terstruktur, observasi dan dokumentasi. Teknik pemeriksaan keabsahan data menggunakan teknik triangulasi sumber dan metode. Data dianalisis dengan menggunakan logika induktif, yakni dari khusus ke umum.

\section{HASIL DAN PEMBAHASAN}

\section{a. Pemahaman Guru terhadap Penilaian} Kompetensi Keterampilan

Pengamatan di lapangan menggambarkan masih banyak guru yang mengalami kesulitan memahami kurikulum pendidikan tahun 2013, khususnya dalam memahami bagaimana cara melakukan penilaian autentik untuk kompetensi keterampilan. Guru sudah memahami bahwa penilaian dalam proses pendidikan merupakan komponen yang tidak dapat dipisahkan dari komponen lainnya khususnya pembelajaran. Penilaian merupakan proses pengumpulan dan pengolahan informasi untuk mengukur pencapaian hasil belajar siswa. Penilaian hasil belajar oleh guru dilakukan untuk memantau proses, kemajuan belajar, dan perbaikan hasil belajar siswa secara berkesinambungan. Guru juga sudah memahami bahwa tujuan penilaian otentik untuk menilai kemampuan siswa terkait dengan dunia nyata, yakni bagaimana siswa mengaplikasikan pengetahuan dan keterampilannya ke dalam tugas-tugas nyata. Dengan penilaian otentik, akan diperoleh informasi yang akurat untuk melihat kemampuan siswa. 
Keterlaksanaan Penilaian Kompetensi Keterampilan Pada Pembelajaran Matematika Berdasarkan Kurikulum 2013

Sintha Sih Dewanti

Guru memahami bahwa

penilaian kompetensi keterampilan dapat berupa portofolio, laporan tertulis, tugas-tugas terstruktur, proyek, demonstrasi, presentasi lisan, dan unjuk kerja. Guru juga memahami mengenai macam-macam instrumen yang digunakan dalam teknik kompetensi keterampilan yaitu berupa angket/ kuesioner, lembar observasi, daftar cek, skala penilaian dan pedoman wawancara. Akan tetapi guru belum memahami rubrik penilaian yang digunakan pada setiap instrumen. Misalnya untuk melakukan penilaian produk, guru hanya menilai berdasarkan produk yang dihasilkan siswa sesuai kriteria yang ditetapkan. Guru tidak melakukan penilaian kemampuan siswa dan merencanakan, menggali, dan mengembangkan gagasan, dan mendesain produk, serta penilaian kemampuan siswa dalam menyeleksi dan menggunakan bahan, alat, dan teknik. Dalam penilaian proyek, guru hanya menilai laporan dari sisi tampilan dan kelengkapan bagian laporan. Guru tidak melalukan penilaian pada aspek persiapan dan pelaksanaan proyek, yaitu ketepatan tujuan, topik, alasan, dan tempat penelitian, serta cara memperoleh data dan kelengkapan data.

Berdasarkan uraian di atas, dapat disimpulkan bahwa guru memahami bahwa penilaian kompetensi keterampilan, tetapi belum semua guru paham tentang cara pelaksanaan penilaian kompetensi keterampilan. Tidak sedikit guru yang hanya sekedar mengerti, tetapi untuk menerapkannya dan menyesuaikan dengan tuntutan kurikulum 2013 masih terdapat kerancuan.

\section{b. Penerapan Penilaian Kompetensi Keterampilan pada Pembelajaran Matematika}

Penerapan Kurikulum 2013 di

DIY dilakukan secara bertahap sejak tahun 2014 dengan jumlah sekolah yang menerapkan terus bertambah setiap tahunnya. Pada awal penerapan Kurikulum 2013 khususnya penilaian autentik ini, guru memang merasa kebingungan karena memang tidak dijelaskan secara rinci dan detail tentang penilaian autentik ini. Namun semakin kesini guru menjadi semakin paham dan lebih jelas mengenai penilaian autentik. Pada pelaksanaan penilaian kompetensi keterampilan guru sering menggunakan daftar cek (check-list) dan skala penilaian.

Penilaian kompetensi keterampilan yang dilakukan oleh guru sebagai berikut.

1) Unjuk kerja/ kinerja/ praktik Penilaian unjuk kerja dilakukan dengan cara mengamati kegiatan siswa dalam melakukan sesuatu. Misalnya ketika guru akan menjelaskan konsep bilangan prima, siswa melakukan praktik menemukan konsep bilangan prima. Guru meminta siswa membuat tabel bilangan $10 \times 10$ yang bertuliskan bilangan 1 sampai 100 secara urut. Kemudian guru meminta siswa melakukan kegiatan berikut: a) Coret bilangan 1 ; b) Coret semua bilangan yang habis dibagi 2 kecuali 2 ; c) Coret semua bilangan yang habis dibagi 3 kecuali 3; d) Coret semua bilangan yang habis dibagi 5 kecuali 5; e) Coret semua bilangan yang habis dibagi 7 kecuali 7. Guru meminta siswa memperhatikan bilangan-bilangan yang tidak di coret. Siswa menemukan kesamaan dari bilangan-bilangan tersebut, yaitu bahwa bilangan tersebut hanya habis dibagi oleh dua bilangan, yaitu bilangan 1 dan bilangan itu sendiri.

Melalui kegiatan tersebut, guru hanya mengamati kinerja siswa 
Halaman 59-68

dalam mengidentifikasi bilangan kelipatan 2, 3, 5, dan 7. Padahal dalam pelaksanaan praktik, sebaiknya guru melakukan beberapa hal sebagai berikut.

a) Menyampaikan rubrik sebelum pelaksanaan penilaian kepada siswa.

b) Memberikan pemahaman yang sama kepada siswa tentang kriteria penilaian.

c) Menyampaikan tugas kepada siswa.

d) Memeriksa kesediaan alat dan bahan yang digunakan untuk tes praktik.

e) Melaksanakan penilaian selama rentang waktu yang direncanakan.

f) Membandingkan kinerja siswa dengan rubrik penilaian.

g) Melakukan penilaian dilakukan secara individual.

h) Mencatat hasil penilaian.

i) Mendokumentasikan hasil penilaian.

2) Proyek

Penilaian proyek dapat digunakan untuk mengetahui pemahaman, kemampuan mengaplikasi, kemampuan menyelidiki dan kemampuan menginformasikan suatu hal secara jelas. Pada materi perbandingan dan skala, guru menugaskan kepada siswa untuk mengamati peta kabupaten tempat tinggal siswa. Siswa diminta menemukan letak rumah, letak sekolah, letak tempat yang paling sering dikunjungi, dan beberapa tempat lain. Siswa diminta mengukur jarak tempat-tempat tersebut dan menentukan jarak sebenarnya dari rumah. Siswa diminta menghitung jarak yang ditempuh dalam 1 bulan untuk mengunjungi tempat-tempat tersebut dengan rumah. Kemudian siswa membuat laporan hasil pengamatan dan persentasikan di depan kelas.

Penilaian proyek dilakukan mulai dari perencanaan, pelaksanaan, sampai pelaporan. Untuk itu, guru perlu menetapkan hal-hal atau tahapan yang perlu dinilai, seperti penyusunan desain, pengumpulan data, analisis data, dan penyiapan laporan tertulis/ lisan. Untuk menilai setiap tahap perlu disiapkan kriteria penilaian atau rubrik. Ada tiga hal yang perlu diperhatikan dalam penilaian proyek yaitu:

a) Kemampuan pengelolaan yang meliputi kemampuan dalam memilih topik (bila belum ditentukan secara spesifik oleh guru), mencari informasi dan mengelola waktu pengumpulan data serta penulisan laporan.

b) Relevansi, yaitu kesesuaian dengan mata pelajaran ditinjau dari segi pengetahuan, keterampilan dan pemahaman selama proses belajar.

c) Keaslian, yaitu proyek yang dilakukan siswa merupakan karya nyata siswa dengan kontribusi guru pada petunjuk dan dukungan.

3) Produk

Penilaian produk adalah suatu penilaian terhadap keterampilan menghasilkan suatu produk dalam waktu tertentu sesuai dengan kriteria yang telah ditetapkan, baik dari segi proses maupun hasil akhir. Penilaian produk meliputi penilaian kemampuan siswa membuat produkproduk, teknologi, dan seni. Pada materi garis dan sudut, guru meminta siswa mengamati bendabenda atau peristiwa yang mengandung unsur sudut istimewa $\left(30^{\circ}, 45^{\circ}, 60^{\circ}\right.$, dan $\left.90^{\circ}\right)$, garis sejajar, garis tegak lurus, sudut sehadap, sudut bertolak belakang, sudut berseberangan, dan sudut sepihak. 
Keterlaksanaan Penilaian Kompetensi Keterampilan Pada Pembelajaran Matematika Berdasarkan Kurikulum 2013

Sintha Sih Dewanti

Siswa diminta mengambil foto atau gambar sketsa benda-benda tersebut, dan menunjukkan letak dari konsep yang telah dipelajari, kemudian membuat laporannya.

Pada penilaian produk, guru melakukan 3 tahap penilaian yaitu:

a) Tahap persiapan, meliputi: penilaian kemampuan siswa dan merencanakan, menggali, dan mengembangkan gagasan, dan mendesain produk.

b) Tahap pembuatan produk (proses), meliputi: penilaian kemampuan siswa dalam menyeleksi dan menggunakan bahan, alat, dan teknik.

c) Tahap penilaian produk (appraisal), meliputi: penilaian produk yang dihasilkan siswa sesuai kriteria yang ditetapkan, misalnya berdasarkan, tampilan, fungsi dan estetika.

4) Portofolio

Penilaian portofolio yang pernah dilakukan guru berupa penilaian karya-karya siswa secara individu pada suatu materi. Berdasarkan hasil portofolio, guru dan siswa sendiri dapat menilai perkembangan kemampuan siswa dan terusmenerus melakukan perbaikan. Guru memberikan tugas berupa pertanyaan-pertanyaan kritis yang harus dikerjakan siswa pada akhir setiap pertemuan pada materi himpunan. Pertanyaan kritis tersebut adalah:

a) Jika $\mathrm{M}$ sebuah himpunan, apakah $M \subset M$ ? Buktikan!;

b) Misalkan A, B, C adalah himpunan, jika $A \subset B$ dan $B \subset C, \quad$ apakah $A \subset C$ ? Buktikan!;

c) Untuk 2 himpunan A dan B yang tidak memiliki irisan, apakah kedua himpunan itu pasti saling lepas? Tunjukkanlah dengan memberikan contoh!;

d) Untuk 2 himpunan A dan B yang memiliki irisan, apakah kedua himpunan itu pasti saling lepas? Mengapa? Berikan contohnya!;

e) Misalkan $A \subset B$ dan $B \subset A$, berapa anggota himpunan $\mathrm{A}-\mathrm{B}$ ? Berikan alasannya!;

f) Misalkan A himpunan kosong, apakah berlaku $A \cup A=A$ dan $A \cap A=A$ ?;

g) Misalkan P dan Q himpunan, maka kondisi apa yang dipenuhi agar $P \cup Q=P$ ? Berikan alasannya!.

Dengan pemberian soal berisi pertanyaan kritis tersebut, maka portofolio dapat memperlihatkan dinamika kemampuan kritis siswa melalui sekumpulan karyanya yang diperoleh dari pengalaman.

c. Problematika Guru dalam Menerapkan Penilaian Kompetensi Keterampilan

Problematika guru matematika dalam menerapkan penilaian kompetensi keterampilan adalah:

1) Penilaian kompetensi keterampilan menyita waktu yang lama bagi guru dikarenakan banyaknya aspek yang harus dinilai, serta banyaknya instrumen dan rubrik penilaian yang harus disiapkan oleh guru. Guru merasa diberatkan pada administrasi, padahal guru sudah dibebani dengan banyaknya materi ajar.

2) Keadaan siswa yang kurang mendukung, untuk beberapa kelas siswa mengalami kesulitan dalam memahami materi dikarenakan banyaknya materi yang harus diserap dalam satu tema serta sulitnya siswa dalam mengumpulkan tugas, sehingga guru harus menagih tugas-tugas siswa agar nilai siswa tidak berada di bawah KKM. 
Halaman 59-68

3) Pada perencanaan penilaian kompetensi keterampilan guru mengalami kesulitan dalam: a) menentukan kompetensi yang penting untuk dinilai; b) menyusun indikator pencapaian kompetensi berdasarkan kompetensi yang akan dinilai; c) menguraikan kriteria yang menunjukkan capaian indikator hasil pencapaian kompetensi; d) menyusun kriteria ke dalam rubrik penilaian; e) menyusun tugas sesuai dengan rubrik penilaian; f) menyusun kriteria/ batas kelulusan/ batas standar minimal capaian kompetensi siswa.

4) Pada pelaksanaan penilaian praktik guru mengalami kesulitan dalam: a) membandingkan kinerja siswa dengan rubrik penilaian; b) melakukan penilaian dilakukan secara individual; c) mencatat hasil penilaian; dan d) mendokumentasikan hasil penilaian.

5) Pada pelaksanaan penilaian proyek guru mengalami kesulitan dalam: a) memberikan pemahaman kepada siswa tentang kriteria penilaian; b) membandingkan kinerja siswa dengan rubrik penilaian; c) memetakan kemampuan siswa terhadap pencapaian kompetensi minimal; dan d) memberikan umpan balik terhadap laporan yang disusun siswa.

6) Pada pelaksanaan penilaian produk guru mengalami kesulitan dalam menilai setiap tahap pengembangan produk, yaitu tahap persiapan, tahap pembuatan produk, dan tahap penilaian produk.

7) Pada pelaksanaan penilaian portofolio guru mengalami kesulitan dalam: a) melaksanakan proses pembelajaran terkait tugas portofolio dan menilainya pada saat kegiatan tatap muka, tugas terstruktur atau tugas mandiri tidak terstruktur, disesuaikan dengan karakteristik mata pelajaran dan tujuan kegiatan pembelajaran; b) melakukan penilaian portofolio berdasarkan kriteria penilaian yang telah ditetapkan atau disepakati bersama dengan siswa; dan c) memberi umpan balik terhadap karya siswa secara berkesinambungan dengan cara memberi keterangan kelebihan dan kekurangan karya tersebut, cara memperbaikinya dan diinformasikan kepada siswa.

\section{KESIMPULAN}

Kesimpulan dari penelitian ini adalah:

a. Pemahaman guru terhadap penilaian kompetensi keterampilan ini cukup baik, guru paham mengenai macam instrumen dan teknik penilaian, akan tetapi belum memahami rubrik penilaian yang digunakan pada setiap instrumen;

b. penerapan penilaian kompetensi keterampilan sudah berjalan dengan cukup baik namun beberapa masih terkendala dan belum sesuai standar penilaian;

c. problematika guru dalam menerapkan penilaian kompetensi keterampilan yaitu: masalah pemahaman penilaian kompetensi keterampilan, waktu, kompleksitas administrasi, keadaan siswa, perencanaan penilaian diantaranya pengembangan instrumen dan rubrik penilaian, dan pelaksanaan penilaian kompetensi keterampilan.

\section{REFERENSI}

Cumming, J. J., \& Maxwell, G. S. 1999. Contextualizing Authentic Assessment. Assessment in Education.

Dewanti, S. S. April 2015. Tinjauan Teoritis tentang Sistem Evaluasi Pembelajaran Matematika di Sekolah Menengah Pertama. Makalah disajikan dalam kegiatan Kuliah Umum, di UIN Sunan Kalijaga Yogyakarta.

Gatlin, L., \& Jacob, S. 2002. Standardsbased digital portfolios: A component of authentic assessment for preservice teachers. Action in Teacher Education.

Grisham-Brown, J., Hallam, R., \& Brookshire, R. 2006. Using authentic assessment to evidence children's progress toward early learning 
standards. Early Childhood Education Journal.

Kemenkumham RI. 2016. Peraturan Menteri Pendidikan dan Kebudayaan Nomor 20 tentang Standar Kompetensi Lulusan Pendidikan Dasar dan Menengah. Jakarta: Direktur Jenderal Peraturan Perundang-undangan Kemenkumham RI.

Kemenkumham RI. 2016. Peraturan Menteri Pendidikan dan Kebudayaan Nomor 23 tentang Standar Penilaian Pendidikan. Jakarta: Direktur Jenderal Peraturan Perundang-undangan Kemenkumham RI.

Linn, R. L. 1989. Educational measurement $\left(3^{\text {th }} e\right.$ d.). New York: American Council on Education/ Macmillan Publishing Company.

Mardapi, D. 2012. Pengukuran penilaian \& evaluasi pendidikan. Yogyakarta: Nuha Medika.

Peraturan Menteri Pendidikan dan Kebudayaan Republik Indonesia Nomor 58 Tahun 2014 Tentang Kurikulum 2013 Sekolah Menengah Pertama/ Madrasah Tsanawiyah.

Peraturan Menteri Pendidikan dan Kebudayaan Republik Indonesia Nomor 104 Tahun 2014 Tentang Penilaian Hasil Belajar oleh Guru pada Pendidikan Dasar dan Pendidikan Menengah.

Peraturan Menteri Pendidikan Nasional Republik Indonesia Nomor 16 Tahun 2007 Tentang Standar Kualifikasi Akademik dan Kompetensi Guru.

Sumarmo, U. 2010. Pengembangan Berpikir dan Disposisi Kritis, Kreatif pada Peserta Didik dalam Pembelajaran Matematika. Makalah dimuat pada Web Sekolah Pascasarjana Universitas Pendidikan Indonesia.

Wiggins, G. 1993. Assessment: Authenticity, context and validity. Phi Delta Kappan. 